Journal of Architectural Research and Education (JARE)

Vol. 1 (2) 168-175

@I Nyoman Nuri Arthana. 2019

DOI: $10.17509 /$ jare.v1i2.22322

\title{
The Knowledge Building of Construction Process of Bali Arya's Architecture: Interpretation of the Manuscript Asta Kosala Kosali
}

\section{Nyoman Nuri Arthana ${ }^{1}$}

${ }^{1}$ Department of Architecture, Faculty of Engineering and Planning, Universitas Warmadewa, Denpasar - Bali, Indonesia

1 Jalan Terompong No. 24 Tanjung Bungkak, Denpasar-Bali, Indonesia

Corresponding Author:nuriarthana60@yahoo.com

Received: 5 Oktober 2019
Revised: 15 November 2019
Article History:

Accepted: 20 Desember Available online: 31 Desember 2019

Abstract - Bali has written rules about building procedures which are traditionally are still used today. The rules are written in an ancient manuscript in the form of a palm leaf known as Asta Kosala Kosali (AKK). The AKK manuscript has been around since the arrival of the Aryans from the Majapahit kingdom to Bali, therefore the architectural products produced in this period are called Bali Arya's architecture. Based on the contents of the AKK script, the disclosure of architectural knowledge is carried out using an architectural perspective in the context of construction. This perspective and context used show that this research is different from previous studies of the AKK manuscripts that use cultural, anthropological, and historical perspectives. This study places the AKK script as the main object of research, therefore the method used is to apply hermenetic operations or called interpretations. Through this research architectural knowledge can be formulated in the context of construction, namely; 1 ) the basic foundation of the construction process that is carried out is truth in the process, obedience to the principles of building and the achievement of pleasure in each stage and its results. 2) The principles applied in the construction process, technically is the assembly of construction components starting from the building body, applying the principle of strong columns weak beams, prioritizing the sustainability of materials, construction and building, and using rational composition of regular geometric shapes to achieve beauty . 3) The basic concept as the ultimate goal of the construction process is the balance and harmony of the relationship between humans, nature and God. These three formulations are components of the building of Bali Arya's architectural knowledge in the context of the construction process.

Keywords: knowledge; construction process; Bali Arya's architecture; interpretation

\section{Introduction}

Bali is one of the provinces in Indonesia which has characteristics of culture, environment, society including distinctive architecture. Typical Balinese architectural forms, one of which is caused by the way or construction process used. Architecture is a beautiful building, starting when arranging its elements attentively, (Klassen, 1990). This view shows that the main elements that determine the form of architecture are the elements of construction including the material, which in its manifestation is influenced by the way they are arranged, arranged and unified. Bali Arya's architecture in its construction process uses the lontar manuscript Asta Kosala Kosali (AKK) as a guide. This AKK text contains philosophical (tattwa), ethical (ethika) and technical (upacara) aspects related to development implementation. Historically, this AKK manuscript has existed since the sixteenth century, when Bali arrived by the Aryans (royal officials) from Majapahit. Based on the historical aspects of this AKK manuscript, the architectural product of that era was called the Bali Arya's architecture.

The AKK text clearly contains guidelines on the implementation of development, but most of the research that has been carried out on this manuscript is in the realm of linguistic, cultural and anthropological knowledge. So far only two studies have been found that use an architectural perspective, namely research conducted by Kagami (1988) and Satria (2015). Previous studies show that there is a knowledge gap in exploring the knowledge contained by the AKK Manuscript. Kagami's 
research is a descriptive study comparing the contents of the AKK script with the physical artifacts of Balinese architecture. Satria conducted research to uncover the aesthetic principles contained in the AKK manuscript. While this research will explore the AKK script by using an architectural perspective in the context of the construction process, aiming to reveal knowledge of Balinese architecture in general and specifically Bali Arya's architecture.

The use of different perspectives and contexts from previous studies, shows that this research is a new research that places the manuscript as its main object. This research will answer the question 'how to build knowledge of Bali Arya's architecture in the architectural perspective and context of the construction process ?, as intended by AKK script. The object of this research is the text or writing which is positioned as a text (Ricouer, 1971), therefore the method used in this study uses the principles of interpretation.

\section{Materials and Methods}

Based on historical tracking, the AKK manuscript is a record of the development process of the Semarapura kingdom located in Klungkung (one of the regencies in Bali), which was carried out by the executor of development from Karangasem's work. Notes on this building process, from Klungkung brought to Karangasem and written in the form of palm-leaf named Asta Kosala Kosali. After that the AKK manuscript was found scattered in several regions in Bali. Considering the historical aspects, this research will use the AKK script sourced from Karangasem, which is precisely now stored in Puri Madurha. While other manuscripts will be positioned as a comparison to clarify the truth of the substance of the AKK manuscript used as the object of research.

Research on the AKK manuscript will be carried out using the method of interpretation (Ricouer, 2014) by applying discrete criticism techniques to decipher the substance of the manuscript, analysis of critical discourse to analyze the manuscript based on the perspective and context of research and logical argumentation (Grout and Wang, 2013) to formulate knowledge building Bali Arya's architecture, according to the AKK script.

\section{Theoretical Review}

Some theoretical views referred to in this study are used to gain an understanding of the perspective and context of research.

\subsection{Knowledge and Architectural Knowledge}

Etymologically Edward (1972: 17) states that knowledge comes from the English word, knowledge. In the Encyclopedia of philosophy explained that the definition of knowledge is true belief (knowledge is justified true belief). Salam (1997: 54), explains the knowledge possessed by humans is classified into four types, namely: 1) ordinary knowledge, 2) science knowledge, 3) philosophical knowledge, and 4) religious knowledge. Kruft (1994: 27), states that architectural knowledge is the result of thought processes that are reasonable and supported by experience. Prijotomo (2006: 2) states that architectural knowledge is knowledge that is cultivated in, about and by architectural disciplines. And it is stressed that architectural knowledge becomes knowledge when its contents and order are accepted in the applicable provisions of knowledge. This research generally places itself in the study of knowledge as a science. In particular this research was in the domain of knowledge about architecture.

\subsection{Architecture and Construction}

Kruft (1994: 27), referring to Vitruvius, explains that architecture is a building that has three main components, namely; Firmity (structure and construction or strength), Utility (function or use) and Venustas (beauty and aesthetics). Kruft also distinguishes architecture as a (physical) product and architecture as a science or knowledge. As an architectural product is the result of practice, while as architectural knowledge is the result of thought processes that are reasonable and supported by experience. Prijotomo (2002: 12), asserted that basically architecture is an environment that is able to become a container for various human activities that have a certain aesthetic charm or meaning. Klassen (1990: 43), explains that architecture is a construction, the form of architecture does not only consist of one material, but consists of many materials that are arranged and arranged into a single form. Klassen also stressed that architecture is a beautiful building that starts when we arrange the elements attentively. Klassen's view shows that the main elements of architecture are the elements of construction (material), which in their manifestations are influenced by the way they are arranged, arranged and united. Porphyrious (1991: 13), states that architecture is a form of art or a form that 
has an equivalent value with works of art. Furthermore, in the context of constructing art, Frampton (1995: 23), states that architecture is an expression of the formation of structures and constructions that are produced through the process of compiling materials in such a way as to create a form that has artistic / artistic dimensions that are not figurative or abstract.

Based on the notion of architecture and construction above, this study uses an architectural perspective that is understood as a form that is produced through the process of uniting, connecting and assembling structural components to present a form capable of accommodating activities with aesthetic charm and meaning.

\section{Kosala Kosala Manuscript Review}

The Asta Kosala Kosalai Manuscript (AKK) is a relic of past written works written in letters and in Kawi languages (a mixture of ancient Javanese, Sanskrit and Balinese letters and languages) on rontal leaf strands, known as lontar. The AKK ejection manuscript is classified into the 'Kanda' type classification. Kanda means code of conduct or procedure for doing something. The classification of AKK into the type of kanda manuscript shows that this manuscript bearing contains a procedure for doing something, which in this case is about the procedures for implementing building construction in Bali.

In connection with the process of building in Bali according to Gelebet (1986), the use of AKK has begun since the pre-construction stage, especially in the activities of makarya, nyanggra, and ngurip gegulak as well as nyikut and ngruak karang, to the construction stage in the form of nglakar and nasarin activities, ngakit and ngerabin as well as ngaug. Each activity was preceded by the implementation of the ritual (upakara) and the determination of the good day (dewasa ayu). And the position of the AKK is as a guide and reference in the implementation of each stage of construction.

Based on the substance, use and position of the AKK manuscript in the building process, this manuscript can be stated as an architectural manuscript. Thus the disclosure of architectural knowledge contained therein can be done, especially in the context of construction.

\section{Knowledge of Bali Arya's architecture}

Based on the stages of interpretation of the manuscript starting from the stage of saying, explaining and translating, the formulation of knowledge of Bali Arya's architecture which was successfully revealed consisted of; 1) the basic foundation of the construction process, 2) the principles of the construction process, and 3) the basic concepts of the Bali Arya architectural construction process.

\subsection{The Base of Construction Process of the Bali Arya's Architecture}

There are two basic principles adopted by the AKK manuscript, set out in article 97, which states, as follows:

\footnotetext{
'Siku siku nga, walik yan ring sarira, ala ayu ning iděpta. Patitis nga, pěměněr ring sarwwa ginawe, yan ring sarira paměněr ring pati lawan urip. Kalinganya manah ta winangun ayu wrěddhi, ika riněngěn juga, yan sira wěruh ring phala, widyaning sarwwa ginawe. ..........' Meaning:

Elbows mean the opposite. If it's on yourself, that is the good and bad of your mind. Patitis means justification (the tool used to make it right) for everything that is made. If inside, the truth is death and life. It also includes your mind which gives birth to virtue, only that which deserves to be heard, if you want to get the results of all that is done
}

The description in this lot contains several principles or fundamentals as the norm in the use or application of AKK. The first principle is to always consider the two opposing poles (such as sikusiku), which are good and bad. Second, the mind (buddhi) is a tool used to achieve truth in everything that is done. The use of buddhi in implementing AKK, has also been stated in lot 1 which '...buddhinta juga wisesa, wi, nga. pangesengan, nga. agni, mungguh ring nabhinta, angesengakna lara roganta, teka geseng.', which means your ultimate buddhi, which can solve all problems. The use of reason in carrying out the construction process, shows that the AKK text is based on rational truth.

The sentence in the AKK ejection script in article 6 states "Iti kadharman Asta Kosali nga, kawruha sang suddha dharmma, weti kinon de nira Bathara Siwa......", which means that the AKK is a means to carry out sacred work, which was compiled by order of Bhatara Siwa and received by 
Sang Citra Gotra and Bhagawan Swakarmma as the authors. The final part of this article states that "sampun putus de nira anyubuhakna", which means this AKK has been perfect to be applied. Both of these sentences show that the AKK text contains truth, so don't hesitate to apply it. These two articles illustrate that the AKK is not a creation or idea from humans but from God. The idea of linking the AKK with the beliefs held by the community, through the mentioning or involving God / Bhatara, a saint called Bhagawan, clearly shows an attempt to sacred the AKK placing it as sacred knowledge. The sacreding of the AKK is intended so that humans obediently and consciously use the AKK as a guide in development and apply it properly.

The AKK manuscript besides containing the technical aspects related to the process, also contains aspects related to the ritual procession. The ritual of implementing the procession in the construction process is carried out in each stage, using infrastructure and facilities that contain sesaji, sesari and mantra. Sesaji are offerings consisting of various types of food. Sesari is an offering in the form of a hole or money pis made from a mixture of metal with a hole in the middle. Mantra are sacred words or sentences spoken as a language of introduction to offerings to God. After sesaji and sesari are offered with a mantra as an introduction, these sesaji and sesari are then given to all parties involved in the construction process. The procedure for its distribution, carried out in accordance with the authority and responsibilities of each of these parties. In connection with this in article 151 of the AKK manuscript, mentioned'......yan sire kipwen pwen de sang angingu, awehakěna sanakta kabeh,....', which means if you are offered or given something (offerings) by the person who gives the job, give it all to your family. Providing offerings to all parties involved in the construction process, to give pleasure or satisfaction, so that the work done with pleasure will get good results. Based on the rituals performed in each construction process, shows the construction process which is based on the pleasure of the process and the results obtained by a pleasant form. Hoping that according to the AKK text is pleasure in terms of process and results.

The description shows how the basis for the construction of the Bali Arya process is the truth called satwam, obedience called siwam and pleasure called sundharam.

\subsection{Principles of Construction Process of the Bali Arya's Architecture}

Technically, the Bali Arya's architecture construction process starts from the determination of the dimensions of sesaka or building columns. Dimensions of this sesaka will be the basis for determining the dimensions of other construction components of a building. Article 8 of the AKK text states that "iti sikut ing yasa, kaweruhakna de sang amangun yasa, pawitan sasaka ika....", meaning that this is the size of the building, it should be known by the person who is going to build the building, starting from the sesaka (column).

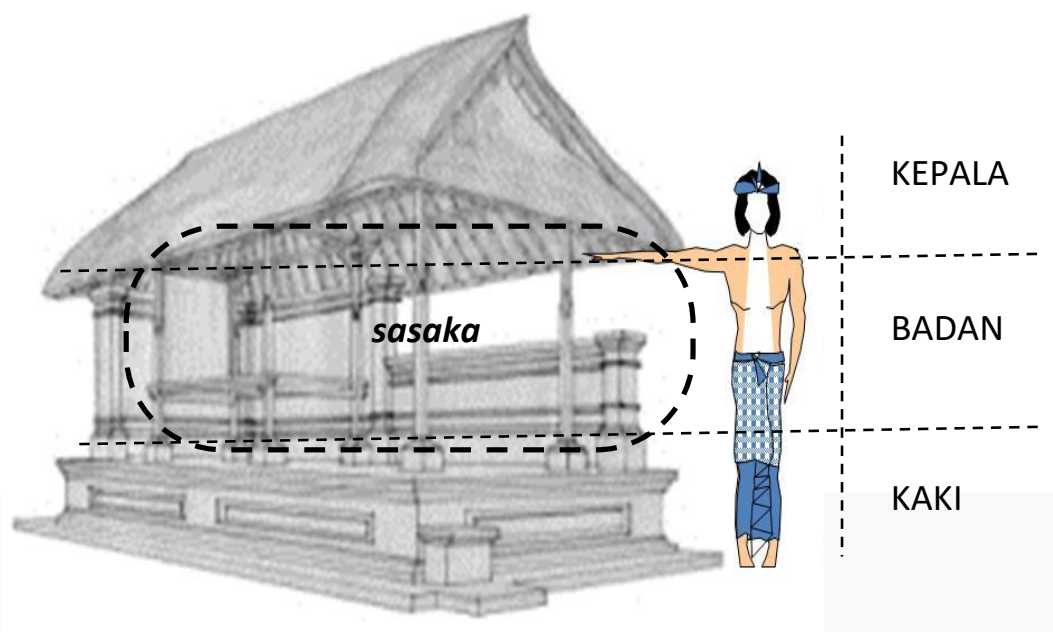

Figure 1. Tri Angga and Building Parts

Referring to the concept of Tri Angga, which divides the building into three parts, namely; 1 ) the head is part of the roof of the building, 2) the body is part of the frame of the building including the walls, and 3 ) the foot is the foundation part of the building. The building columns is located on the building body part, therefore as stated by AKK ejection, the construction process of Bali Arya's architecture starts from the building body part. 
The contents of this article also indicate that the dimensions of the building colums are the most important and structurally important, in this case the dimensions of the building columns determine the strength of the building. By placing the columns as the main component of the building structure, conceptually shows that the structural planning principle adopted is the strong column weak beam concept. Frick (1998), explains that buildings that use a structural frame system, have major components in the form of columns and beams. The principle applied in the planning and design of buildings using a structural frame system is strong columns and weak beams. This principle considers the safety factor of building users, where if there is a failure in the building, then the beam first collapses, at least the signs of collapse can be known in advance (eg deflection or cracks in the beam or sound from the beam), so that humans in the building still have time or opportunity to save themselves.

The AKK text referred to in articles 110.111 and 112, also regulates the classification and use of wood species in construction components, as in table 1 below.

Table 1. Classification and Use of Wood

\begin{tabular}{|c|c|c|c|c|}
\hline No & $\begin{array}{l}\text { Fungsi } \\
\text { Bangunan }\end{array}$ & Nama Kayu & Klasifikasi & $\begin{array}{l}\text { Keterangan Penggunaan } \\
\text { Pada Bagian Bangunan }\end{array}$ \\
\hline \multirow{5}{*}{ A } & \multirow{5}{*}{$\begin{array}{l}\text { Parahyangan } \\
\text { (tempat suci) } \\
\text { Lot } 110\end{array}$} & Cendana & Prabhu & Rangka Atap \\
\hline & & Menengen & Patih & Kolom \\
\hline & & Cempaka & Arya & Kolom dan/atau Balok \\
\hline & & Kwanditan & Tumenggung & Balok \\
\hline & & Suren & Rangga & Dinding \\
\hline \multirow{6}{*}{ B } & \multirow{6}{*}{$\begin{array}{l}\text { Bale (tempat tidur) } \\
\text { Lot } 111\end{array}$} & Nangka, Kwanditan, Kampwak & Prabhu & Rangka Atap \\
\hline & & Jati, Juwet & Patih & Kolom dan/atau Balok \\
\hline & & Benda, Gentimun & Arya & Dinding \\
\hline & & Timbul, Kaliasem & Tumenggung & Bale-bale \\
\hline & & Sentul, Boni & Rangga & Pelengkap Bagian Atap \\
\hline & & Sukun, Bulwan & Demung & Ornamen \\
\hline \multirow{6}{*}{ C } & \multirow{6}{*}{$\begin{array}{l}\text { Jineng dan Paon } \\
\text { (tempat bahan dan } \\
\text { pengolahan } \\
\text { makanan) } \\
\text { Lot } 112\end{array}$} & Wangkal & Prabhu & Rangka Atap \\
\hline & & Kutat & Patih & Kolom \\
\hline & & Blalu & Arya & Balok \\
\hline & & Buu & Tumenggung & Lantai \\
\hline & & Endep & Demung & Bale-bale \\
\hline & & \multicolumn{3}{|c|}{$\begin{array}{l}\text { Catatan : } \\
\text { - } \quad \text { Bila ada kayu berbuah tanpa bunga, tidak boleh dipakai dapur. } \\
\text { - } \quad \text { Bila berbuah berasal dari bunga itu boleh dipakai dapur, Wreksa namanya. }\end{array}$} \\
\hline
\end{tabular}

Source: AKK Manuscript

The classification and regulation of the use of wood in a part of the building is intended to utilize wood effectively and efficiently. On the other hand regulating the use of wood is an effort to avoid and control the use of one type of wood in large quantities (a lot), considering that wood requires time to grow until it meets the requirements as a construction material in a relatively long period. This is an implementation of the concept of sustainable materials, which will ultimately guarantee the creation of sustainable buildings and constructions. On the other hand the prohibition of using wood from trees that bear fruit but does not bloom for kitchen buildings, aims to maintain the security of kitchen buildings from the threat of vulnerability to fire hazards. This confirms again that sustainable buildings and constructions, are principles that are conceptually adhered to by the AKK.

In the context of form, the AKK text contains rules relating to three main parts of the building, namely; the foot, called bebataran, is the elevation or distance between the ground and the floor of the building, the body part called pengawak consists of sesaka arranged in a modular arrangement with a lambang (beam above the column) and sunduk (stiffening beam) and the head is called raab or payon, in the form of sineb (coupling beam) and a series of iga-iga (rafters). Geometrical forms of Bali Arya's architecture, based on the AKK manuscript, can be seen in the following figure. 

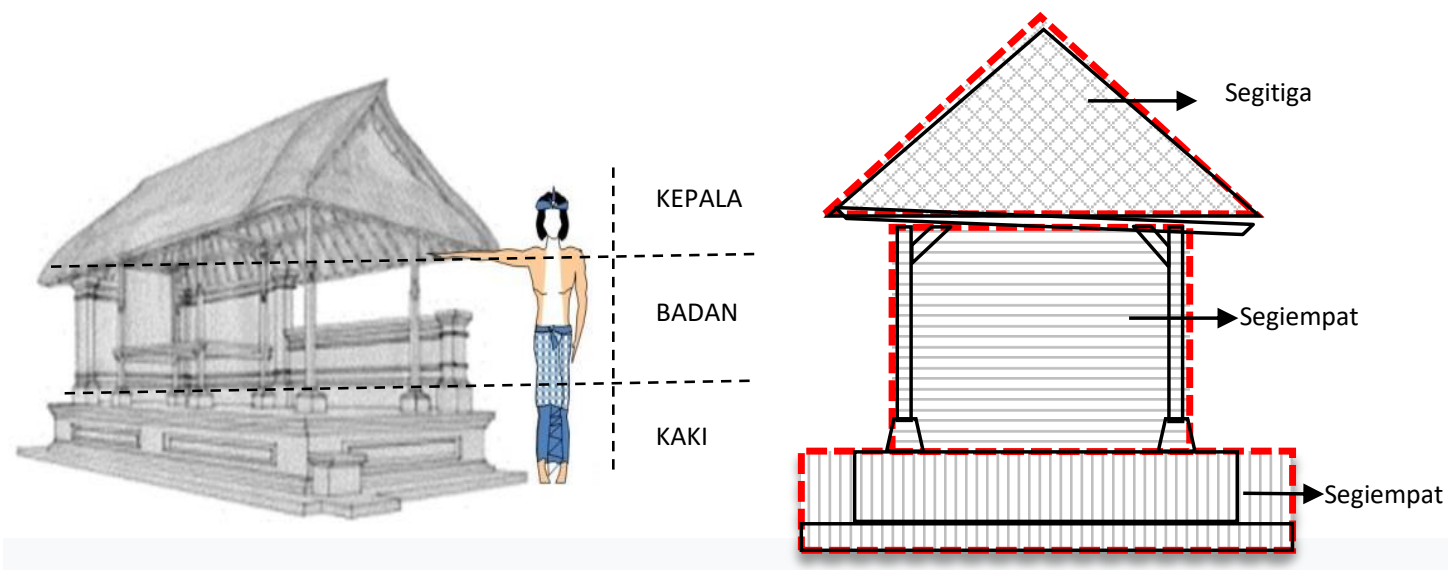

Figure 2. Buildings Geometric Forms

Geometrically, the foot of the building is rectangular, the body part is rectangular and the head of the building is triangular. Rectangular and triangular shapes are the basic shapes of geometry (other than circles). The triangular shape has a rational, stable and sturdy character on the side position, unstable and dynamic at the point and directed position. Whereas quadrilateral has a rational character, simple and innocent (as is), neutral and static, directed and not directed, can be dynamic at the point position. The geometric-regular shape of the Bali Arya's architecture arises from the consequences of applying the rules of measurement, measurement and calculation of building components. On the other hand, the arrangement of geometric shapes in Bali Arya's architecture also shows the existence, unity; form arranged into a unified whole in a building, harmony; one form with another does not show contradiction, it appears that one another accepts mutual acceptance, symmetry; the present form illustrates the similarity between the left and the right, if folded, they can overlap, and balance; the shape shows the weight similarity both in quality and quantity between the left and right when viewed from the axis of the building which is exactly in the middle. Thus the Arya Balinese architectural form has a simple, stable visual character indicating the existence of unity, harmony, symmetry and balance.

\subsection{Basic Concepts of Construction Process of the Bali Arya's Architecture}

The earliest part of the AKK states that 'tingkah uriping kayu ring sariranta', which means the nature of the life of wood is in humans. An analogy that represents how humans should behave towards wood (read: nature). The statement has two meanings, namely; 1 ) human and nature are one entity that cannot be separated, in this case nature as a container, while humans as their contents. 2) humans, nature and all of its contents are both living things or objects that are considered to have life. Both of these meanings indicate human relations with nature, a symbiotic mutualism, a relationship that is mutually beneficial, caring for and caring for (Frick, 1998).

The AKK manuscript also mentions the methods adopted to preserve and care for nature, where the manuscript mentions 'uriping kayu kayu ika, ulihakna maring pradhana, nga. Prathiwi' and 'kapatyaning kayu kabeh, ulihakna maring purusa. Purusa, nga Akasa'. This means returning wood life to the ground and wood death returning to the sky. The return of living wood to the soil, means replanting, as an effort to maintain the natural balance and availability of wood. Returning wood to the sky means optimizing the use of wood that is already in the form of waste, even though it is no longer useful (read: dead) for anything. To be returned to heaven the only way is to burn it. Utilization of wood by burning can be done in its use as firewood, for cooking, burning citakan (rectangular ground mold that has not yet become brick) or converted into an adang (charcoal) that can be used by the pande (people who have the skills to make equipment from iron / metal) in their work. Thus the wood will not be in vain, all can be utilized and even after becoming ashes is also useful, such as a mixture of soil in the making of slides, additives for slides for walls in buildings, or plastering on the floors and walls of buildings and walls of shearers (walls border of the yard). The return of dead wood (waste) is an effort to reuse and at the same time destroy or reduce wood waste from the construction process is an effort to protect nature from pollution or negative impacts caused by the waste. 
On the other hand the sentence in the AKK above is a form of awareness for humans, that building somehow is an activity that has the potential to damage nature. Cutting down trees for building materials, digging soil for foundations, including disposing of waste from the construction process are examples of building activities that can pollute and destroy nature. The AKK text provides direction that the relationship that humans must build with nature in architecture and construction is a harmonious and balanced relationship. Thus the basic concept of the construction process adopted by the AKK is harmony and balance.

\section{Conclusions}

Knowledge of Bali Arya's architecture is substantially rational and historically empirical. At this point the resulting architectural work (borrowing a term from Rasmussen, 1980) is a geophysical architectural work, which is based on experience and geometric architectural works based on calculations. The basic foundation of architecture in the context construction process of the Bali Arya's architecture in accordance with the AKK script is truth (satwam), obedience (siwam) and pleasure (sundharam). The principle of the construction process that is applied is the principle of strong column - weak beam, the principle of construction starts assembling components from the body part of the building, the principle of material, construction and building sustainability, and the principle of regular geometry beauty. All construction process activities carried out to achieve balance and harmony both in the process and the results achieved. Bali Arya's architecture knowledge building, diagrammatically can be described as follows:

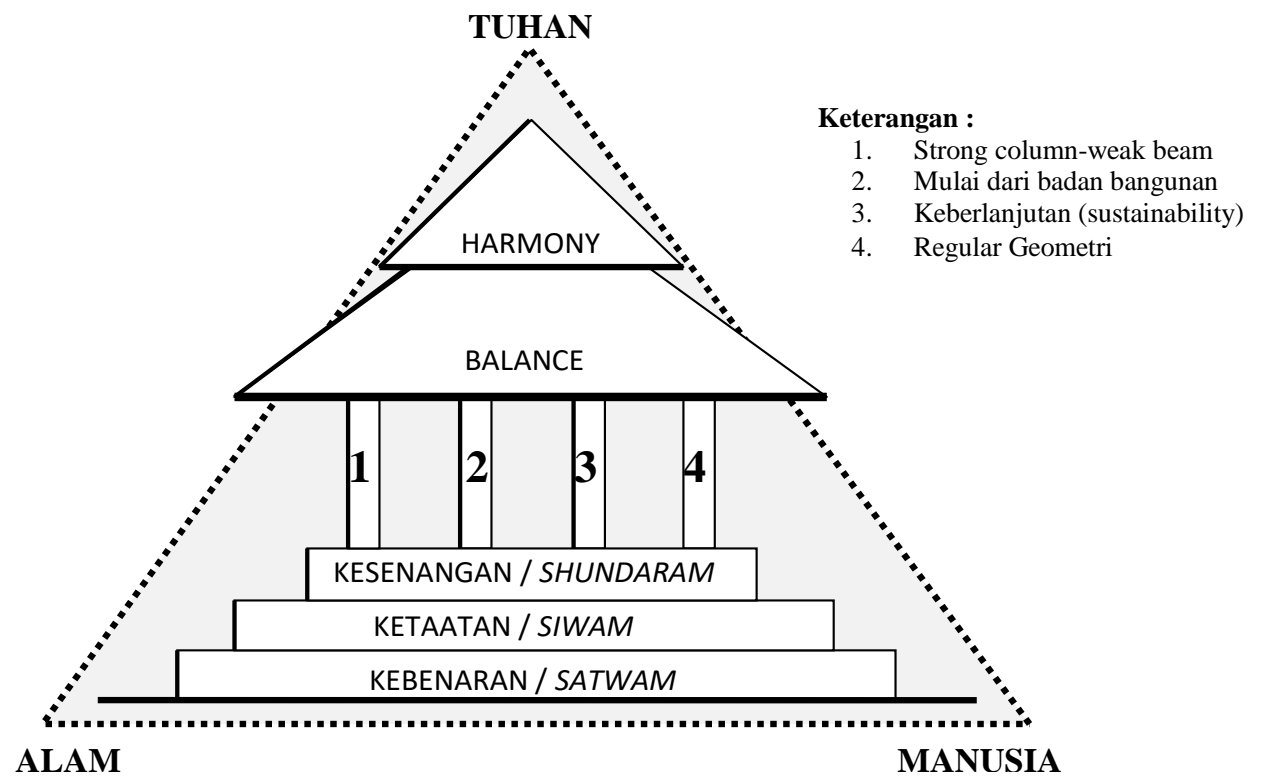

Figure 3. Schematic Buildings Knowledge of Construction Process of Bali Arya's Architecture

\section{References}

Frampton, Kenneth, 1995, Studies in Tectonic Culture, The MIT Press, London.

Heinz Frick, 1998, Sistem Bentuk Struktur Bangunan: Dasar-Dasar Konstruksi Dalam Arsitektur, Kanisius, Yogyakarta

Grout, Linda and Wang, David, 2013, Architectural Research Method, Second Edition, John Wiley and Sons, Inc., New Jersey

Gelebet, I Nyoman, 1986, Arsitektur Tradisional Bali, Departemen Pendidikan dan Kebudayaan Propinsi Bali, Denpasar.

Kagami, Haruya, 1988, Balinese Traditional Architecture in Process, Little World Museum of Man, Japan

Klassen, Winnand, 1990, Architecture and Philosophy: Phenomenology, Hermeneutics, Deconstruction, University of San Carlos Press, Cebu City, Philippines. 
Kruft, Hano-Walter, 1994, A History of Architectural Theory from Vitruvius to The Present, Princeton Architectural Press, London

Prijotomo, Josef, 2006, (Re)Konstruksi Arsitektur Jawa : Griya Jawa dalam Tradisi Tanpatulisan, PT. Wastu Lanas Grafika, Surabaya

Porphyrios, Demetry, 1991, Classical Architecture; The Living Tradition, McGraw-Hill, Inc, London. Rassmussen, S., E., 1980, Experirencing Architecture, The MIT Press, USA

Ricoeur, Paul, 1971, The Model of The Text: Meaningful Action Cinsidered as Text, Social Research, vol 38 , h. $529-555$

-, 2014, Teori Interpretasi : Membelah Makna dalam Anatomi Teks, IRCiSoD, Yogyakarta.

Satria, Wina, Ni Made, 2015, Kajian Estetika Arsitektur Bali, tidak di publikasikan, Thesis program magister arsitektur Institut Teknologi Sepuluh Nopember, Surabaya

Salam, Burhanuddin, 1996, Logika Material: Filsafat IImu Pengetahuan, Rineka Cipta, Bandung. 